\title{
Hubungan Frekuensi Perawatan Payudara dengan Kelancaran Produksi ASI pada Ibu Nifas Hari ke 4
}

\author{
Mariyatul Qiftiyah ${ }^{1}$, Eva Silviana Rahmawati², Aris Puji Utami³, Nur Maziyah Hurin'in ${ }^{4}$ \\ STIKES Nahdlatul Ulama Tuban, email : iqtadabi@gmail.com
}

\begin{abstract}
Abstrak. ASI memberi semua energi dan nutrisi yang dibutuhkan bayi selama 6 bulan pertama hidup bayi, sehingga dianjurkan untuk enam bulan pertama bayi hanya diberi ASI Ekslusif tanpa tambahan makanan atau minuman lain. Penelitian ini bertujuan untuk menganalisa hubungan frekuensi perawatan payudara dengan kelancaran produksi ASI pada ibu nifas hari ke 4. Metode penelitian yang digunakanan adalah analitik observasional dengan pendekatan cross sectional. Populasi dalam penelitian adalah seluruh ibu nifas hari ke 4 di BPS Asri dan Polindes Permata Bunda Tuban bulan Juli AgustusTahun 2020, sampel penelitian adalah sebagian ibu nifas hari ke 4 di BPS Asri dan Polindes Permata Bunda Tuban bulan Juli - Agustus Tahun 2020. Teknik sampling yang digunakan dalam penelitian ini adalah simple random sampling. Variabel independen dalam penelitian ini adalah frekuensi perawatan payudara sedangkan variabel dependen dalam penelitian ini kelancaran produksi ASI. Analisis data dalam penelitian menggunakan korelasi Spearman dengan batasan signifikan jika p-value $<0,05$. Analisa hasil penelitian menunjukkan $p$-value $=0,000$ yang berarti terdapat hubungan antara frekuensi perawatan payudara dengan kelancaran produksi asi pada ibu nifas hari ke 4. Pentingnya ASI bagi bayi maka ibu nifas diharapkan selalu menjaga kelancaran ASI dengan cara melakukan perawatan payudara secara rutin dan benar.
\end{abstract}

Kata kunci. Perawatan payudara, ASI, Nifas

\section{The Correlation between The Frequency of Breast Care and The Smooth Production of Breast Milk on Day 4 Postpartum}

Abtract.Breastmilk provides all the energy and butrition a baby needs for the first 6 months of baby life. The firts six months only exclusive breastfeeding is provided for babies without any additional food or drink. This study aims to analyze the correlation between the breast care frequency and the smooth production of breastmilk in post-partum mothers on day 4. The research method was observational analytic with a cross-sectional approach. The study population was all-day 4 postpartum mothers and the study sample were some of the fourth days' postpartum mothers at BPS Asri and Polindes Permata Bunda Tuban in March-April 2020. The research sampling was simple random sampling. The independent variable was the frequency of breast care, while the dependent variable was the milk production smoothness. Data analysis used the Spearman correlation with significant limits of $p$-value $<0.05$. The analysis of the results showed a p-value $=0.000$, which means that there was a correlation between the breast care frequency and the breastmilk smooth production in postpartum mothers on day 4. The importance of breastfeeding for babies is that postpartum mothers are expected to always maintain the smooth running of breast milk by doing regular and correct breast care.

Keywords. Breast care, breast milk, postpartum

\section{Pendahuluan}

Data Profil Kesehatan Indonesia Tahun 2017 cakupan pencapaian pemberian ASI eksklusif pada bayi usia 0-6 bulan adalah $35,73 \%$, sedangkan Pemerintah melalui kementrian kesehatan sudah menargetkan pencapaian asupan ASI ekslusif tahun 20152019 sebesar 85\%. ASI merupakan makanan dan minuman terbaik untuk bayi dalam masa enam bulan pertama kehidupannya, karena ASI memberi semua energi dan nutrisi yang dibutuhkan bayi selama 6 bulan pertama hidupnya, sehingga dianjurkan untuk enam bulan pertama bayi hanya diberi ASI Ekslusif tanpa tambahan makanan atau minuman lain. (Mardiani dkk, 2019). 
Laktasi merupakan seluruh proses menyusui mulai ASI diproduksi sampai bayi menghisap dan menelan ASI, selanjutnya manajemen laktasi adalah suatu upaya yang di lakukan oleh ibu, ayah, dan keluarga untuk menunjang keberhasilan menyusui, namun tidak semua ibu pascasalin bisa memberikan ASI-nya pada bayi karena terganggu produksi ASInya. (Dewi, 2019; Mardiani, 2019).

Masalah menyusui salah satunya adalah puting susu nyeri, puting susu lecet, payudara bengkak dan mastitis. Perawatan payudara seharusnya dilakukan sejak masa kehamilan sebagai upaya persiapan menyusui bayi. Pengetahuan ibu menyusui tentang manfaat dan dampak perawatan payudara terhadap kelancaran produksi ASI akan berpengaruh terhadap perilaku untuk melakukan perawatan payudara (Dewi, 2019).

Kegagalan proses menyusui dapat disebabkan oleh faktor ibu, faktor bayi, faktor psikologis, faktor sosial budaya, dan tenaga kesehatan. (Hesti dkk, 2017). Kelancaran produksi ASI dapat dipengaruhi oleh beberapa faktor meliputi frekuensi pemberian ASI, Berat Bayi saat lahir usia kehamilan saat bayi lahir, usia ibu dan paritas, stres dan penyakit akut, Inisiasi Menyusu Dini, perokok, alkohol, perawatan payudara, penggunaan alat kontrasepsi, status gizi, teknik menyusui, rawat gabung, dan obat-obatan. ASI yang tersedia lancar pada ibu menyusui akan menjadi kesuksesan pemberian ASI Eksklusif selama 6 bulan, sehingga diharapkan tumbuh kembang bayi baik (Dewi, 2019; Pranajaya\&Rudiyanti, 2013).

Produksi ASI yang kurang menjadi salah satu penyebabnya orang tua memutuskan untuk memberikan susu formula kepada bayi. UNICEF menegaskan bahwa bayi yang diberikan susu formula memiliki kemungkinan mortalitas dan morbiditas di bulan pertama kelahiran mereka, dan kemungkinan bayi diberi susu formula adalah 25 kali lipat lebih tinggi dalam angka kematian dibandingkan bayi yang diberikan ASI eksklusif dari Ibu (Hesti dkk, 2017).

ASIyang belum bisa keluar pada hari pertama kehidupan bayi seharusnya bisa di antisipasi sejak kehamilan melalui konseling laktasi. Sekitar $\quad 60 \%$ masyarakat mengetahui informasi tentang ASI dan hanya sekitar $40 \%$ tenaga kesehatan terlatih yang bisa memberikan konseling menyusui. Maka perlu u ntuk ibu dalam mencegah pemberian susu formula karena ASI yang tidak keluar di hari pertama diantaranya dengan melakukan konseling perawatan payudara agar bisa dilakukan Ibu saat setelah melahirkan (Wulandari dkk, 2018).

Pentingnya perawatan payudara sebagai salah satu faktor yang mempengaruhi produksi ASI maka dalam penelitian ini menganalisa hubungan frekuensi perawatan payudara dengan kelancaran produksi ASI pada ibu nifas hari ke 4 .

\section{Metode}

Metode penelitian yang digunakanan adalah analitik observasional dengan pendekatan cross sectional. Populasi dalam penelitian ini adalah seluruh ibu nifas hari ke 4 di BPS Asri dan Polindes Permata Bunda Tuban bulan Juli Agustus Tahun 2020, sampel penelitian ini adalah sebagian ibu nifas hari ke 4 di BPS Asri dan Polindes Permata Bunda Tuban bulan Juli - AgustusTahun 2020. Lokasi penelitian akan dilakukan di BPS Asri dan Polindes Permata Bunda Tuban. Teknik sampling yang digunakan dalam penelitian ini adalah probability sampling dengan menggunakan pendekatan metode simple random sampling. Variabel independen dalam penelitian ini adalah frekuensi perawatan payudara sedangkan variabel dependen dalam penelitian ini kelancaran produksi ASI.

Perawatan payudara dilakukan agar payudara sehat dan tidak terjadi infeksi. Durasi perawatan payudara adalah 15 menit, gerakan yang dilakukan meliputi (1) menyokong payudara kiri dengan tangan kirim, kemudian dilakukan gerakan kecil dengan dua atau tiga jari tangan kanan mulai pangkal payudara dan berakhir dengan gerakan spiral pada puting 
susu, (2) gerakan memutar dengan menekan pangkal payudara dan berakhir pada puting susu di seluruh bagian payudara, (3) kedua telapak tangan diantara dua payudara, dari tengah ke atas sambil mengangkat payudara dan dilepaskan berlahan, gerkan dilakukan kurang lebih $30 \mathrm{kali}$, (4) menyangga payudara dengan satu tangan sedangkan tangan lain mengurut payudara dengan sisi kelingking dari pangkah payudara ke arah putih susu dilakukan 30 kali kemudian meletakkan satu tangan di atas dan satu tangan dibawah payudaara, kedua tangan meluncur secara bersamaan ke arah puting dengan cara memutar tangan (Saryono, 2009).

Kriteria inklusi dalam penelitian ini Ibu menyusui nifas hari ke 4 tanpa susu formula, ibu nifas pasca melahirkan normal pervagina. Kriteria eksklusi Ibu menyusui nifas hari ke 4 yang mengalami infeksi/sakit. Ibu menyusui nifas hari ke 4 yang sudah menggunakan KB pasca salin, Ibu yang bayinya meninggal, Ibu postpartumblues, bayi lahir preterm/BBLR.

Kelancaran produksi ASI dinilai dari kuisioner dengan cara melakukan wawancara dengan indikator (1) ASI keluar merembes melalui puting susu, (2) sebelum menyusi payudara terasa tegang, (3) bayi akan buang air kecil 6-8 kali dalam seahri (4) turgor kulit dan tonus otot bayi baik (5) bayi tampak puas diatndadi dengan bayi akan segera tertidur, tidak sering menangis. Analisis data dalam penelitian menggunakan statistic nonparametris teknik analisis bivariat dengan menggunakan korelari Spearman dengan bantuan SPSS. Untuk menyatakan bahwa terjadi hubungan yang bermakna pada sampel dapat diketahui dengan cara membandingakn $r$ hitung dengan nilai $r$ tabel untuk Spearman Rank Correlation. Batasan signifikan jika $p$ value $<0,05$.

\section{Hasil Penelitian}

1. Analisa hubungan antara frekuensi perawatan payudara dengan kelancaran produksi asi pada ibu nifas hari ke $4 \mathrm{di}$ BPS Asri dan Polindes Permata Bunda Tuban bulan Juli - Agustus Tahun 2020.

Tabel 1. Hasil Penelitian Hubungan Frekuensi Perawatan Payudara dengan Kelancaran Produksi ASI pada Ibu Nifas Hari ke 4 di BPS Asri dan
Polindes Permata Bunda Tuban bulan Juli - Agustus Tahun 2020. $($ Sampel $=34)$.

\begin{tabular}{|c|c|c|c|c|}
\hline \multirow{2}{*}{$\begin{array}{c}\text { Frekuensi } \\
\text { Perawatan } \\
\text { Payudara/Hari } \\
\text { (Durasi } 15 \\
\text { Menit/Perawat } \\
\text { an) }\end{array}$} & \multicolumn{4}{|c|}{ Kelancaran ASI } \\
\hline & Lancar & $\%$ & $\begin{array}{l}\text { Tidak } \\
\text { Lancar }\end{array}$ & $\%$ \\
\hline $2 \mathrm{x} /$ lebih & 13 & 86,7 & 2 & 13,3 \\
\hline $1 \mathrm{x}$ & 4 & 44,4 & 5 & 55,6 \\
\hline Tidak Pernah & 1 & 10 & 9 & 90 \\
\hline Total & 18 & 52,9 & 16 & 47,1 \\
\hline$p=0,000$ & & & & \\
\hline
\end{tabular}

Hasil penelitian menunjukkan sebagian besar responden produksi ASI lancar sebesar 18 responden $(52,9 \%)$ dan hampir setangah reponden melakukan perawatan payudara $2 x$ atau lebih dalam sehari sebanyak 15 responden $(44,1 \%)$ analisa menggunakan uji statistik Spearman mendapatkan hasil $p$ value $=0,000$, karena nilai $\mathrm{p}<0,05$ yang menunjukkan terdapat hubungan antara frekuensi perawatan payudara dengan kelancaran produksi asi pada ibu nifas hari ke 4 .

\section{Pembahasan}

Hasil analisa penelitian menggunakan uji statistik Spearman menunjukkan hasil $\mathrm{p}$ value $=0,000$, karena nilai $p<0,05$ yang menunjukkan bahwa terdapat hubungan antara frekuensi perawatan payudara dengan kelancaran produksi asi pada ibu nifas hari ke 4 .

Teknik meningkatkan produksi ASI meliputi perawatan payudara, senam payudara, payudara pijat oksitosin. Perawatan payudara perawatan payudara untuk memperlancar payudara susu dan hindari kesulitan saat menyusui dengan melakukan pijatan. Perawatan payudara merangsang reseptor di sistem duktus, menyebabkan duktus menjadi lebar dan lembut, sehingga melepaskan oksitosin dari kelenjar hipofisis posterior. Saat terjadi stimulasi hormon oksitosin, sel-sel alveolar 
di kelenjar payudara akan berkontraksi sehingga menyebabkan keluarnya air susu yang mengalir melalui saluran kecil payudara dan air susu keluar menetes yang disebut dengan refleks let down (Hesti dkk, 2017; Wulandari dkk, 2018).

Keberhasilan menyusui tergantung dari produksi ASI yang dihasilkan oleh ibu setelah melahirkan. ASI diproduksi dari hasil kerjasama antara faktor hormonal. Hormon estrogen berperan menjaga tekstur dan fungsi payudara membesar dan merangsang pertumbuhan kelenjar ASI. ASI diproduksi setiap saat sebelum, selama dan sesudah mayi menyusu. ASI yang telah diproduksi disimpan dalam payudara ibu. Pada minggu bulan terakhir kehamilan, kelenjar-kelenjar produksi ASI mulai menghasilkan ASI. Apabila tidak ada kelainan pada hari pertama sejak bayi lahir akan dapat menghasilkan 50-100 ml sehari dan akan terus bertambah sehingga mencapai sekitar $450-450 \mathrm{ml}$ pada waktu mencapai usia minggu kedua. Produksi ASI yang mencukupi atau berlebihan akan berpengaruh terhadap peningkatan berat badan bayi (Aliyanto \& Rosmadewi, 2019).

Pengetahuan ibu menyusui tentang manfaat dan dampak perawatan payudara terhadap kelancaran produksi ASI akan berpengaruh terhadap perilaku untuk melakukan perawatan payudara (Dewi, 2019).

Perawatan payudara adalah perawatan yang dilakukan pada payudara supaya payudara tetap sehat dan tidak terjadi infeksi (Saryono, 2014). Perawatan payudara merupakan suatu tindakan perawatan payudara yang dilaksanakan, baik oleh pasien maupun dibantu oleh orang lain yang dilaksanakan mulai hari pertama atau kedua setelah melahirkan, perawatan payudara bermanfaat untuk memelihara kebersihan payudara, melancarkan keluarnya ASI, mencegah bendungan pada payudara dan mencegah payudara bengkak (Anggraeni, 2010).
Kelancaran ASI dapat dilihat dari beberapa kriteria yang dapat dipakai sebagai patokan untuk mengetahui jumlah ASI lancar atau tidak lancar adalah sebagai berikut: ASI yang banyak dapat merembes melalui putting susu, sebelum disusukan payudara terasa tegang, payudara lembek setelah disusukan, bayi buang air kecil minimal 6 kali dalam sehari, bayi BAB berwarna kekuningan berbiji, bayi tertidur setelah menyusu (Ambarwati \& Wilandari, 2009). Jumlah air susu dikatakan lancar yang keluar kira-kira 550-1000 ml setiap hari, dan umumnya ASI keluar 2-3 setelah melahirkan (Saleha, 2009).

Faktor yang dapat mengakibatkan bias pada hubungan antar variabel seperti pada responden dengan perawatan payudara rutin tetapi ASI masih tidak lancar kemungkinan dapat dipengaruhi beberapa faktor seperti perlekatan posisi menyusi yang belum tepat, perlekatan yang tepat menjadikan bayi menyusu dengan mudah dan jumlah cukup sehingga meningkatkan produksi ASI. Nutrisi Ibu menyusui juga harus dengan gizi seimnang memenuhi kalori, protein, lemak dan vitamin meneral dan dianjurkan minum kurang lebih 8-12 gelas/hari (Oriza, 2019).

Kelancaran produksi ASI pada penelitian sebagian menunjukkan sebagian responden lancar, ibu mengerti tentang perawatan payudara dan hampir setengah responden telah melaksanakan perawatan payudara minimal $2 x$ sehari, tetapi ibu juga perlu kontrol ke bidan selama 4 kali kunjungan .

\section{Simpulan}

Pentingnya ASI bagi bayi maka ibu nifas diharapkan selalu menjaga kelancaran ASI dengan cara melakukan perawatan payudara secara rutin dan benar, selain itu ibu nifas juga harus tetap memperhatikan kebersihan tubuh sehari-hari, pemasukan gizi ibu harus lebih baik dan lebih banyak untuk mencukupi produksi ASI, ibu harus percaya diri akan kemampuan menyusui bayi, ibu harus merasa nyaman dan santai, 
hindari rasa cemas dan stres karena akan menghambat reflek oksitosin.

\section{Ucapan Terimakasih}

Penulis mengucapkan terimakasih kepada seluruh respoonden dan tempat penelitian BPS Asri dan Polindes Permata Bunda Tuban.

\section{Daftar Pustaka}

Aliyanto, W. \& Rosmadewi, 2019. Efektifitas Sayur Pepaya Muda dan Sayur Daun Kelor terhadap Produksi ASI pada Ibu Post Partum Primipara. Jurnal Kesehatan, 10(1), pp. 84-92.

Ambarwati, E. R. \& Wilandari, D., 2009. Asuhan Kebidanan Masa Nifas. 1 ed. Ygyakarta: Mitra.

Anggraeni, Y., 2010. Asuhan Kebidanan Masa Nifas. 1 ed. Yogyakarta: Rinek Cipta.

Dewi, A. D. C., 2019. Faktor-faktor yang mempengaruhi kelancaran produksi asi. Jurnal 'Aisyiyah Medika, 4(1), pp. 22-34.

Hesti, K. Y. et al., 017. Effect of combination of breast care and oxytocin massage on breast milk secretion in postpartum mothers. Belitung Nursing Journal, 3(6), pp. 784-790.
Mardiani, N., Oktaviania, P. O. p. \& Afianti, F., 2019. Pengaruh Pemberian ASI Booster terhadap Produksi ASI Ibu Post Sectio Cesarea. Jurnal Kesehatan Pertiwi, 1(1), pp. 2631.

Oriza, Novalita. 2019. Faktor yang mempengaruhi bendungan ASI pada Ibu Nifas. Nursing Arts, 14(1), pp. 2940.

Pranajaya, R. \& Rudianti, N., 2013. Determinan produksi asi pada ibu menyusui. Jurnal Keperawatan, Volume IX, No. 2, Oktober 2013, 10(2), pp. 227-237.

Saleha, S., 2009. Asuhan Kebidanan pada Masa Nifas. 1 ed. Jakarta: Salemba Medika.

Saryono, 2014. Perawatan Payudara. 1 ed. Yogyakarta: Nuha Medika.

Wulandari, P., Kustriyani, M. \& Aini, K., 2018. Peningkatan Produksi ASI Ibu Post Partum melalui Tindakan Pijat Oksitosin. Jurnal Ilmiah Keperawatan Indonesia, 2(1), pp. 33-49. 